\title{
PENGARUH PENDEKATAN PEMBELAJARAN BERBASIS MASALAH TERHADAP PENINGKATAN KEMAMPUAN KOMUNIKASI DAN PEMECAHAN MASALAH MATEMATIS SISWA KELAS IX SMP NEGERI KECAMATAN SUNGAI PENUH
}

\author{
Megawati, S.Pd., M.Pd \\ STIA NUSANTARA SAKTI SUNGAI PENUH
}

\begin{abstract}
This research was started from students' low communication ability and mathematical problem solving at grade IX SMP Negeri Kecamatan Sungai Penuh. To solve the problems, thus the writer applied problem-based learning approach. By using problem solving activity the students was guided to understand the concept and to find the characteristics of the subject material, so that the students would be trained to propose their mathematical idea and to develop problem solving ability. The aim of this research was to know the effect of problem-based approach toward enhancement of communication ability and students' mathematical problem solving at grade IX SMP Negeri Kecamatan Sungai Penuh. This research was conducted based on the quasi experimental research.. To get the sample, the writer used random sampling technique. T-Test and U-Test was used to analyze the data. Based on the result of the data analysis, the writer got some conclusions that was the enhancement of communication ability and students' mathematical problem solving that using problem-based approach was better than using conventional teaching approach.
\end{abstract}

Key Words: pembelajaran berbasis masalah, komunikasi matematis, pemecahan masalah matematis 


\section{Pendahuluan}

Tujuan pembelajaran matematika dalam KTSP yaitu agar peserta didik memiliki kemampuan memahami konsep matematika, menggunakan penalaran pada pola dan sifat atau menjelaskan gagasan dan pernyataan matematika, memecahkan masalah matematika, mengkomunikasikan gagasan matematika, dan memiliki sikap mengahargai kegunaan matematis dalam kehidupan (Depdiknas, 2006).

Diantara kemampuan matematis yang telah diungkapkan oleh Depdiknas, kemampuan komunikasi dan pemecahan masalah matematis merupakan kemampuan yang penting dikuasai siswa dalam pembelajaran matematika. Dalam pembelajaran matematika kemampuan siswa da-lam menyatakan ide atau gagasannya dalam memecahkan suatu soal perlu dikembangkan dan diperhatikan oleh guru. Disamping itu banyak kalangan dan pakar matematika merekomendasikan agar pemecahan masalah menjadi fokus utama dalam pembelajaran matematika (NCTM, 2000) dan pada hakekatnya be-lajar matematika adalah pemecahan masalah (Halmos dalam Fauzan, 2012).

Komunikasi matematika menjadi1 perhatian dalam pembelajaran matematika karena untuk mengkomunikasikan gaga-san, informasi atau persoalan dengan ba-hasa matematika justru lebih praktis, siste-matis, dan efisien misalnya dalam bentuk diagram, persamaan, grafik, ataupun tabel (Depdiknas dalam PPPG, 2004:20).

Kemampuan komunikasi matema-tis yaitu keterampilan siswa dalam menya-takan ide tau gagasan dalam bentuk simbol, grafik, lambang, tabel ataupun pernyataan matematika. Melalui komu-nikasi matematis, pemikiran dan ide matematika siswa dapat direpresentasikan de-ngan jelas dan lebih praktis dalam berbagai bentuk.

Selain itu pemecahan masalah juga perlu dikembangkan dalam pembelajaran matematika. Pemecahan masalah matema-tis merupakan keterampilan siswa mela-kukan manipulasi dan menggunakan atau memilih strategi penyelesaian dalam me-mecahkan masalah yang diberikan oleh guru. Melalui kegiatan pemecahan masa-lah siswa memanfaatkan pengalaman yang dimiliknya untuk memperoleh penge-tahuan. Pengetahuan ini dapat berupa keterampilan siswa dalam menyelesaian soal-soal non rutin dan menemukan pola jawaban.

Berdasarkan hasil laporan TIMSS (Third International Mathematics Science Study) tahun 2003 menempatkan Indone-sia pada posisi 34 dari 45 negara, dan lebih separuh pelajar kelas II dan kelas III SLTP di Indonesia berada dibawah stan-dar rata-rata skor Internasional. Selanjut-nya menurut hasil PISA pada tahun 2006 Indonesia ranking 50 dari 57 peserta dan tahun 2009 yang Indonesia ranking 61 dari 65 peserta. Data-data ini mengindika-sikan bahwa masih rendahnya kemampuan matematis siswa SMP di Indonesia di mata Internasional. 
Rendahnya kemampuan matematis siswa SMP khususnya komunikasi dan pemecahan masalah matematis juga terja-di di tingkat lokal seperti di Kecamatan Sungai Penuh. Hasil ini diperoleh melalui tes kemampuan komunikasi dan pemecahan masalah matematis yang diberikan kepada siswa SMP Negeri Kecamatan Sungai Penuh.

Berdasarkan hasil tes diketahui bahwa kemampuan matematis siswa yang meliputi kemampuan komunikasi dan pemecahan masalah matematis masih kurang memuaskan. Untuk kemampuan komunikasi matematis rata-rata skor yang diperoleh siswa adalah 5,665 dari skor ideal 12. Begitu pula dengan pemecahan masalah, rata-rata skor yang dicapai siswa adalah 3,013 dari skor ideal 10.

Pada umumnya, kesalahan siswa dalam menyelesaikan soal komunikasi matematis adalah siswa masih kesulitan menyajikan ide matematika dengan menggunakan hubungan-hubungan yang diketa-hui, sehingga kesimpulan akhir yang dipe-roleh siswa menjadi salah. Begitupun da-lam menyelesaikan soal pemecahan masa-lah, kelemahan siswa terlihat dalam pemi-lihan strategi penyelesaian yang kurang tepat yang menyebabkan kesimpulan menjadi salah.

Berdasarkan hasil observasi dan wawancara yang dilakukan dengna guru dan siswa, faktor penyebab rendahnya ha-sil belajar siswa yang dilihat dari kemampuan komunikasi dan pemecahan masalah matematis diantaranya adalah karena guru kurang mengoptimalkan proses pembe-lajaran dan tidak memilih suatu model, metode, pendekatan, atau strategi pembe-lajaran yang dapat mengkonstruksi pengetahuan siswa, sehingga siswa tidak terlatih untuk mengerjakan soal-soal selain yang dicontohkan oleh guru pada waktu menje-laskan pelajaran. Sebenarnya guru telah melakukan berbagai upaya untuk menga-tasi hambatan dan masalah dalam proses pembelajaran, hanya saja belum optimal.

Salah satu pendekatan pem-belajaran yang dianggap bisa digunakan untuk mengembangkan kemampuan ko-munikasi matamatis pemecahan masalah siswa adalah dengan pendekatan pembe-lajaran berbasis masalah (PBM). PBM merupakan salah satu alternatif pembela-jaran yang dapat mengembangkan keterampilan berpikir siswa (penalaran, komu-nikasi, dan koneksi) dalam memecahkan masalah (Rusman, 2010:229). PBM dikembangkan untuk membantu siswa dalam mengembangkan kemampuan berpikir, memecahkan masalah, dan keterampilan intelektual (Hamruni, 2012:104). Jadi dengan pembelajaran berbasis masalah diharapkan kemampuan berpikir siswa akan lebih meningkat.

Ciri utama pembelajaran berbasis masalah adalah pengajuan pertanyaan atau masalah yang merupakan starting point dalam pembelajaran. Melalui masalah yang telah diajukan, guru mengarahkan siswa untuk melakukan penyelidikan terhadap masalah dengan menggunakan pendekatan berpikir secara ilmiah baik proses berpikir deduktif maupun induktif, kerjasama, dan menghasilkan karya serta memperagakan hasil karya. 
PBM tidak dirancang untuk mem-bantu guru memberikan informasi sebanyak-banyaknya kepada siswa. PBM antara lain bertujuan untuk membantu siswa mengembangkan keterampilan berpikir dan keterampilan pemecahan masalah. Dalam PBM, perhatian pembe-lajaran tidak hanya pada hasil belajar siswa tetapi juga pada proses belajar siswa.

Langkah-langkah kegiatan dalam PBM yaitu: a) merumuskan masalah, yaitu siswa menentukan masalah yang akan dipecahkan, b) menganalisis masalah, ya-itu langkah siswa meninjau masalah secara kritis dari berbagai sudut pandang, c) merumuskan hipotesis, yaitu siswa me-rumuskan berbagai kemungkinan pemecahan sesuai dengan pengetahuan yang dimilikinya. d) mengumpulkan data, yaitu langkah siswa mencari dan menggam-barkan informasi yang diperlukan untuk pemecahan masalah, e) menguji hipotesis, yaitu langkah siswa mengambil atau merumuskan kesimpulan sesuai dengan penerimaan dan penolakan hipotesis yang diajukan, dan f) merumuskan rekomen-dasi, yaitu langkah siswa menggambar-kan rekomendasi yang dapat dilakukan sesuai rumusan hasil pengujian hipotesis dan rumusan kesimpulan (John Dewey dalam Hamruni, 2012:110).

Berdasarkan konsep PBM ini, diharapkan siswa mampu memahami konsep materi pelajaran, sehingga pembelajaran akan lebih bermakna dan dapat bertahan lebih lama dalam ingatan siswa. Belajar akan lebih bermakna jika siswa mengalami sendiri yang dipela-jarinya, serta mengetahui maksud dan tujuan materi yang dipelajarinya. Dengan pendekatan pembelajaran yang tepat diha-rapkan kemampuan komunikasi mate-matis dan pemecahan masalah matematis siswa dapat meningkat.

Selain pemilihan pendekatan pembelajaran yang tepat, faktor lain yang dapat mempengaruhi keberhasilan siswa dalam belajar adalah kemampuan awal. Kemampuan awal yang dimiliki siswa akan menunjang proses pembelajaran dengan pendekatan berbasasis masalah, karena dalam kegiatan pemecahan masalah akan banyak melibatkan kemampuan berpikir siswa dalam menyelesaikan masalah, sehingga kemampuan yang telah dimiliki siswa akan sangat mendukung proses pemecahan masalah. Kemampuan awal dalam penelitian ini bertujuan untuk melihat pembelajaran berbasis masalah lebih cocok digunakan pada kelompok siswa yang berkemampuan awal tinggi, sedang atau rendah.

Komunikasi matematika adalah kemampuan siswa dalam menjelaskan suatu algoritma dan cara unik untuk pemecahan masalah, kemampuan siswa mengkonstruksikan dan menjelaskan sajian fenomena dunia nyata secara grafis, kata-kata atau kalimat, persamaan, tabel dan sajian secara fisik atau kemampuan siswa memberikan dugaan tentang gambar-gambar geometri (NCTM, 2000).

Indikator kemampuan komunikasi matematis yang diukur dalam penelitian ini diantaranya: a) menyatakan suatu situasi, gambar, diagram, atau benda nyata ke dalam bahasa, simbol, ide, atau model matematika; b) menyajikan ide-ide dengan 
menggunakan hubungan yang diketahui, dan c) melakukan perhitungan dan membuat kesimpulan (membuat generalisasi).

Pemecahan masalah adalah serangkaian operasi kognitif yang dilakukan untuk menemukan suatu solusi dari masalah. Operasi kognitif yang dimaksud melibatkan dua hal, yaitu memahami masalah dan konteksnya secara mental dan kemudian secara aktif melakukan manipulasi untuk mencoba strategi atau model pemecahan masalah (Anderson dalam Fauzan, 2012).

Indikator pemecahan masalah yang diukur dalam penelitian ini yaitu: a) mengidentifikasi unsur-unsur yang dike-tahui, yang ditanyakan, dan kecukupan unsur yang diperlukan; b) merumuskan masalah matematika atau menyusun model matematik; c) menerapkan strategi untuk menyelesaikan berbagai masalah dalam atau di luar matematika; dan d) menjelaskan atau menginterpretasikan hasil sesuai permasalahan asal.

\section{Metode Penelitian}

Berdasarkan permasalahan dan tujuan penelitian, maka jenis penelitian ini adalah quasi eksperimen. Penggunaan jenis penelitian quasi eksperimen dikarenakan variabel penelitian tidak mungkin dikontrol secara penuh. Penelitian ini dilakukan terhadap dua kelompok yaitu kelas eksperimen yang diberi perlakuan dengan menggunakan pendekatan pem-belajaran berbasis masalah dan kelas kontrol yang diberi perlakuan dengan menggunakan pendekatan pembelajaran konvensional. Terhadap kedua kelas sampel akan diberi pengukuran yang sama yaitu berupa Pre-test dan Post-test. Variabel dalam penelitian ini terdiri dari a) variabel bebas yaitu pendekatan pembelajaran berbasis masalah; b) varia-bel terikat yaitu kemampuan komunikasi dan pemecahan masalah matematis; dan c) variabel moderator yaitu kemampuan awal siswa.

Rancangan penelitian yang digu-nakan dalam penelitian ini adalah Randomized Pre-test-Post-test Kontrol Group Design. Seperti terlihat pada Tabel 1.

Tabel 1. Rancangan Penelitian

\begin{tabular}{|c|c|c|c|}
\hline Kelas & $\begin{array}{c}\text { Pre- } \\
\text { test }\end{array}$ & Perlakuan & $\begin{array}{c}\text { Post- } \\
\text { test }\end{array}$ \\
\hline Eksperimen & $\mathrm{O}$ & $\mathrm{X}$ & $\mathrm{O}$ \\
Kontrol & $\mathrm{O}$ & - & $\mathrm{O}$ \\
\hline
\end{tabular}

Keterangan:

$\mathrm{X}$ : Pembelajaran dengan menggunakan pembelajaran berbasis masalah 
Pembelajaran dengan menggunakan pembelajaran konvensional

- : Pre-test $=$ Post-test untuk melihat kemampuan komunikasi dan peme-cahan masalah matematis siswa

$\mathrm{O}$ :

Berdasarkan rancangan penelitian yang digunakan, maka hubungan antar variabel dalam penelitian ini dapat dilihat pada Tabel 2.

Tabel 2. Hubungan antara Variabel Kemampuan Matematis, Ke-mampuan Awal, dan Pende-katan Pembelajaran

\begin{tabular}{|c|c|c|}
\hline $\mathbf{B}$ & $\mathbf{B}_{1}$ & $\mathbf{B}_{2}$ \\
\hline Tinggi $\left(\mathrm{A}_{1}\right)$ & $\mathrm{A}_{1} \mathrm{~B}_{1}$ & $\mathrm{~A}_{1} \mathrm{~B}_{2}$ \\
\hline Sedang $\left(\mathrm{A}_{2}\right)$ & $\mathrm{A}_{2} \mathrm{~B}_{1}$ & $\mathrm{~A}_{2} \mathrm{~B}_{2}$ \\
\hline Rendah $\left(\mathrm{A}_{3}\right)$ & $\mathrm{A}_{3} \mathrm{~B}_{1}$ & $\mathrm{~A}_{3} \mathrm{~B}_{2}$ \\
\hline
\end{tabular}

Keterangan:

$\mathrm{B}=$ Pembelajaran

A $\quad=$ Kemampuan awal

$\mathrm{B}_{1} \quad=$ Pembelajaran Berbasis Masalah

$\mathrm{B}_{2} \quad=$ Pembelajaran Konvensional

$\mathrm{A}_{1} \mathrm{~B}_{1}=$ Gain skor kemampuan komu-nikasi matematis siswa berke-mampuan awal tinggi yang di-ajar dengan pendekatan PBM

$\mathrm{A}_{1} \mathrm{~B}_{2}=$ Gain skor kemampuan komuni-kasi matematis siswa berke-mampuan awal tinggi yang diajar dengan pendekatan kon-vensional

$\mathrm{A}_{2} \mathrm{~B}_{1}=$ Gain skor kemampuan komu-nikasi matematis siswa berke-mampuan awal sedang yang diajar dengan pendekatan PBM

$\mathrm{A}_{2} \mathrm{~B}_{2}=$ gain skor kemampuan komuni-kasi matematis siswa berke-mampuan awal sedang yang diajar dengan pendekatan kon-vensional 
$\mathrm{A}_{3} \mathrm{~B}_{1}=$ gain skor kemampuan komuni-kasi matematis siswa berke-mampuan awal rendah yang diajar dengan pendekatan PBM

$\mathrm{A}_{3} \mathrm{~B}_{2}=$ gain skor kemampuan komuni-kasi matematis siswa berke-mampuan awal rendah yang diajar dengan pendekatan kon-vensional

Tabel winner untuk pemecahan masalah matematis siswa sama dengan Tabel 2.

Populasi dalam penelitian ini adalah seluruh siswa kelas IX SMP Negeri seKecamatan Sungai Penuh yang terdaftar pada semester II tahun ajaran 2013/2014, yang terdiri dari 4 sekolah. Pengambilan sampel dilakukan dengan teknik Random Sampling dan diperoleh kelas IX.B SMP Negeri 2 Kecamatan Sungai Penuh sebagai kelas eksperimen dan kelas IX.A SMP Negeri 9 Kecamatan Sungai Penuh sebagai kelas kontrol.

Instrumen yangdigunakan dalam penelitian ini adalah berupa soal tes kemampuan awal, Pre-test, dan Post-test. Analisis data dilakukan dengan menggunakan uji $t$ dan uji U. pengujian hipotesis menggunakan bantuan software SPSS 17.

\section{Hasil dan Pembahasan}

Untuk menarik kesimpulan tentang data peningkatan kemampuan komunikasi dan pemecahan masalah matematis siswa kelas sampel dilakukan analisis secara statistik. Sebelum melakukan uji hipotesis maka terlebih dahulu dilakukan uji persyaratan analisis yang meliputi uji normalitas dengan menggunakan uji Kolmogorov-Smirnov dan uji homogenitas dengan uji Levene terhadap nilai gain ternormalisasi kelas eksperimen dan kelas kontrol. Jika data berdistribusi normal maka dilanjutkan dengan melakukan uji homogenitas variansi, namun jika data tidak berdistribusi normal tidak dilakukan uji homogenitas variansi.

Berdasarkan uji persyaratan ana-lisis, maka hipotesis 1, 2, 3, 4, 5, 6, dan 8 diuji dengan menggunakan uji U karena data tidak berdistribusi normal, sedangkan hipotesis 7 menggunakan uji $t$ karena data berdistribusi normal.

Hasil uji hipotesis peningkatan kemampuan komunikasi dan pemecahan masalah matematis dapat dilihat pada Tabel 3.

\section{Tabel 3. Hasil Uji Hipotesis}

\begin{tabular}{|c|c|c|c|}
\hline Hipotesis & $\mathbf{N}$ & Nilai Sig. & Ket. \\
\hline $\begin{array}{c}\text { Hipotesis } \\
1\end{array}$ & 32 & 0,000 & $\begin{array}{c}\text { Hipotesis } \\
\text { diterima }\end{array}$ \\
\cline { 2 - 2 } 27 & & \\
\hline
\end{tabular}




\begin{tabular}{|c|c|c|c|}
\hline $\begin{array}{c}\text { Hipotesis } \\
2\end{array}$ & 5 & 0,0225 & $\begin{array}{c}\text { Hipotesis } \\
\text { diterima }\end{array}$ \\
\hline $\begin{array}{c}\text { Hipotesis } \\
3\end{array}$ & 20 & 0,000 & $\begin{array}{c}\text { Hipotesis } \\
\text { diterima }\end{array}$ \\
\hline $\begin{array}{c}\text { Hipotesis } \\
4\end{array}$ & 2 & 0,0495 & $\begin{array}{c}\text { Hipotesis } \\
\text { diterima }\end{array}$ \\
\hline $\begin{array}{c}\text { Hipotesis } \\
5\end{array}$ & 27 & 0,001 & $\begin{array}{c}\text { Hipotesis } \\
\text { diterima }\end{array}$ \\
\hline $\begin{array}{c}\text { Hipotesis } \\
6\end{array}$ & $\begin{array}{l}6 \\
5\end{array}$ & 0,003 & $\begin{array}{c}\text { Hipotesis } \\
\text { diterima }\end{array}$ \\
\hline $\begin{array}{c}\text { Hipotesis } \\
7\end{array}$ & 20 & 0,000 & $\begin{array}{c}\text { Hipotesis } \\
\text { diterima }\end{array}$ \\
\hline $\begin{array}{c}\text { Hipotesis } \\
8\end{array}$ & 2 & 0,5 & $\begin{array}{c}\text { Hipotesis } \\
\text { ditolak }\end{array}$ \\
\hline
\end{tabular}

Dari Tabel 3 diketahui bahwa untuk hipotesis 1, 2, 3, 4, 5, 6, dan 7 nilai sig. $<0,05$ yang berarti $\mathrm{H}_{0}$ ditolak dan $\mathrm{H}_{1}$ diterima, sehingga hipotesis yang diajukan diterima. Dari hasil pengujian hipotesis 8 diperoleh nilai sig. $>0,05$ artinya $\mathrm{H}_{0}$ diterima dan $\mathrm{H}_{1}$ ditolak, sehingga hipotesis yang diajukan ditolak.

Berdasarkan hasil uji hipotesis 1, 2, 3, dan 4 diketahui bahwa peningkatan kemampuan komunikasi matematis siswa yang menggunakan pembelajaran berbasis masalah lebih baik daripada yang meng-gunakan pembelajaran konvensional. Se-lanjutnya hasil uji hipotesis 5, 6, dan 7 menunjukkan bahwa peningkatan pemeca-han masalah matematis siswa yang meng-gunakan pembelajaran berbasis masalah lebih baik daripada yang menggunakan pembelajaran konvensional, begitupun de-ngan siswa yang berkemampuan awal tinggi dan sedang. Namun hasil uji hipotesis 8 memperlihatkan hasil yang berbeda yaitu peningkatan pemecahan masalah matematis siswa berkemampuan awal 
rendah yang menggunakan pembe-lajaran berbasis masalah tidak lebih baik daripada siswa berkemampuan awal rendah yang menggunakan pembelajaran konvensional.

Hasil analisis untuk uji hipotesis 1, 2, 3, dan 4 menunjukkan bahwa peningkatan kemampuan komunikasi matematis siswa yang menggunakan pembelajaran berbasis masalah lebih baik daripada yang menggunakan pembelajaran konvensional. Hal ini dikarenakan selama mengikuti pembelajaran dengan PBM siswa dilatih untuk lebih aktif berpikir dan meng-komunikasikan ide-idenya dalam meme-cahkan masalah yang diajukan oleh guru. Hal ini sesuai dengan pendapat Hamruni (2012:107) dimana salah satu ciri utama pembelajaran berbasis masalah yaitu pem-belajaran berbasis masalah tidak meng-harapkan siswa hanya sekedar mendengar, menghapal, dan mencatat materi pelajaran akan tetapi melalui PBM siswa aktif berpikir, berkomunikasi, mencari dan me-ngolah data dan akhirnya menyim-pulkan.

Proses komunikasi matematis siswa dikembangkan oleh guru melalui proses pemecahan masalah dengan membimbing siswa merumuskan masalah dan memberikan pertanyaan-pertanyaan penuntun yang mengarahkan siswa dalam mengkomunikasikan ide-ide matematika.

Terdapat beberapa tahapan dalam pembelajaran berbasis masalah, yaitu merumuskan masalah, menganalisis masalah, merumuskan hipotesis, mengumpulkan data, menguji hipotesis, dan merumuskan rekomendasi (John Dewey dalam Hamruni, 2012:110). Dari tahapan-tahapan itu terdapat 3 tahapan yang paling berpengaruh dalam mengembangkan ke-mampuan komunikasi matematis siswa yaitu, "menganalisis masalah", "meru-muskan hipotesis", dan "mengumpulkan data".

Pada tahap "menganalisis masalah" siswa dibimbing untuk meninjau dan memahami masalah secara kritis dari berbagai sudut pandang dengan menggunakan kemampuan awal yang telah dimiliki siswa, selanjutnya siswa dibim-bing untuk mendefinisikan masalah (Wena, 2011:94). Melalui tahapan ini siswa secara berkelompok berusaha me-mahami masalah dan menafsirkan suatu masalah kontekstual ke dalam bahasa matematika bisa berupa membuat simbol atau gambar dan berupa ide matematika.

Tahapan selanjutnya adalah "me-rumuskan hipotesis". Dalam tahapan ini siswa diarahkan merumuskan berbagai kemungkinan pemecahan masalah atau menyusun berbagai alternatif jawaban sesuai dengan pengetahuan yang dimilikinya dan berdiskusi dalam kelom-poknya melalui proses berpikir ilmiah. Dalam tahapan ini, siswa akan dilatih merumuskan hipotesis dalam berbagai bentuk representasi matematis.

Tahapan selanjutnya yang tidak kalah penting dalam mengembangkan kemampuan komunikasi matematis adalah "mengumpulkan data". Mengumpulkan data yaitu langkah siswa mencari dan menggambarkan informasi yang diper-lukan 
untuk pemecahan masalah (John Dewey dalam Hamruni, 2012:110). Tahapan ini mendorong siswa untuk mengumpulkan informasi yang relevan dan memilih data yang sesuai untuk pemecahan masalah kemudian memeta-kan dan menyajikannya dalam berbagai representasi matematis.

Pada pembelajaran konvensional, guru menjelaskan materi dan memberikan contoh soal dan meminta siswa me-ngerjakan soal latihan. Pembelajaran berlangsung seperti ini pada setiap pertemuannya. Guru memberikan bebe-rapa soal untuk dikerjakan di rumah yang berbentuk soal-soal komunikasi dan pemecahan masalah matematis, namun banyak siswa yang tidak mampu men-jawab soal-soal tersebut, siswa hanya bisa mengerjakan soal seperti yang dicon-tohkan saja karena siswa tidak dilatih untuk mengembangkan kemampuan ko-munikasi dan pemecahan masalah matematis.

Hasil pengujian hipotesis 5, 6, dan 7 menunjukkan bahwa peningkatan pemecahan masalah matematis siswa yang menggunakan pembelajaran berbasis masalah lebih baik daripada yang meng-gunakan pembelajaran konvensional. Hal ini dapat terjadi karena dalam penerapan pembelajaran berbasis masalah guru mela-tih kemampuan siswa dalam memecahkan masalah kontekstual yang diberikan pada awal kegiatan pembelajaran. Selain itu siswa dibimbing untuk menyelesaikan masalah melalui diskusi kelompok.

Pada hakikatnya pembelajaran ber-basis masalah memberikan kesempatan kepada siswa untuk bereksplorasi me-ngumpulkan dan menganalisis data secara lengkap untuk memecahkan masalah yang diberikan. Selain itu pembelajaran berbasis masalah juga dapat melatih peme-cahan masalah siswa serta membuat tantangan intelektual siswa (Uno dan Muhammad, 2011: 112).

Setiap tahapan dalam pembela-jaran berbasis masalah sangat mempengaruhi perkembangan pemecahan masa-lah siswa. Mulai dari tahap siswa merumuskan masalah, menganalisi masalah, merumuskan hipotesis, mengumpulkan data, menguji hipotesis, hingga tahap akhir yaitu merumuskan rekomendasi pemecahan masalah. Pembelajaran berba-sis masalah dikembangkan untuk membantu siswa dalam mengembangkan ke-mampuan berpikir, memecahkan masalah, dan keterampilan intelektual (Hamruni, 2012:104).

Berdasarkan pengamatan yang dila-kukan selama proses pembelajaran dengan menggunakan pendekatan berbasis masa-lah, siswa dalam kelompok yang terdiri dari kemampuan awal tinggi, sedang, dan rendah aktif berdiskusi dalam meme-cahkan masalah. Siswa berkemampuan awal sedang termotivasi oleh teman satu kelompoknya yang berkemampuan awal tinggi dalam melakukan penyelesaian terhadap masalah yang diberikan guru dalam LKS. Dalam hal ini tentunya guru juga membimbing jalannya diskusi dan menuntun siswa melakukan pemecahan masalah. Guru mengoptimalkan fungsi masing-masing individu di dalam kelompoknya agar menjadi lebih aktif dan berpartisipasi dalam memecahkan masa-lah. 
Meningkatnya pemecahan masalah matematis siswa berkemampuan awal tinggi dan sedang di kelas eksperimen tidak terjadi pada siswa berkemampuan awal rendah. Dari pengujian hipotesis kedelapan diperoleh hasil bahwa pening-katan pemecahan masalah matematis sis-wa berkemampuan awal rendah yang menggunakan pembelajaran berbasis ma-salah tidak lebih baik daripada siswa berkemampuan awal rendah yang meng-gunakan pembelajaran konvensional.

Sesuai dengan pengamatan yang dilakukan, hal ini terjadi karena siswa berkemampuan awal rendah merasa kesu-litan menyelesaikan masalah yang diberikan karena masalah yang diberikan umumnya belum pernah mereka pelajari dan memiliki kompleksitas yang tinggi. Meskipun proses pemecahan masalah dilaksanakan melalui diskusi kelompok, tetap saja siswa berkemampuan awal rendah merasa kesulitan untuk memberikan argumen ataupun ide-ide dalam menyelesaikan masalah. Akhirnya siswa berke-mampuan awal rendah kebanyakan hanya duduk mendengarkan teman-temannya berdiskusi tanpa memberikan masukan yang berarti.

Pengamatan yang dilakukan di kelas kontrol menunjukkan bahwa siswa hanya menerima penjelasan dari guru. Siswa banyak diam dan kegiatan siswa lebih banyak mencatat dan mendengarkan penjelasan guru, walaupun sesekali ada siswa yang bertanya mengenai materi yang sedang guru jelaskan dan mengenai cara menyelesaikan soal pemecahan masa-lah. Dalam menyelesaikan soal latihan kebanyakan siswa mengerjakan dengan teman sebangku dan terlihat banyak siswa yang hanya menunggu jawaban dari teman yang bisa menyelesaikan soal. Hal ini menyebabkan siswa tidak terlatih untuk mengembangkan pemecahan masa-lahnya, sehingga jika siswa dihadapkan dengan soal-soal pemecahan masalah, maka siswa akan kesulitan meme-cahkannya.

\section{Kesimpulan}

bahwa:

Berdasarkan hasil analisis data yang telah dilakukan maka dapat disimpulkan

1. peningkatan kemampuan komunikasi matematis siswa yang menggunakan pembelajaran berbasis masalah lebih baik daripada yang menggunakan pembelajaran konvensional.

2. peningkatan kemampuan komunikasi matematis siswa berkemampuan awal tinggi, sedang dan rendah yang menggunakan pembelajaran berbasis masalah lebih baik daripada siswa berkemampuan awal tinggi, sedang, dan rendah yang menggunakan pembelajaran konvensional.

3. peningkatan pemecahan masalah ma-tematis siswa yang menggunakan pembelajaran berbasis masalah lebih baik daripada yang menggunakan pembelajaran konvensional. 
4. peningkatan pemecahan masalah matematis siswa berkemampuan awal tinggi dan sedang yang menggunakan pembelajaran berbasis masalah lebih baik daripada siswa berkemampuan awal tinggi dan sedang yang menggunakan pembelajaran konven-sional.

5. peningkatan pemecahan masalah ma-tematis siswa berkemampuan awal rendah yang menggunakan pembela-jaran berbasis masalah tidak lebih baik daripada siswa berkemampuan awal rendah yang menggunakan pembelaja-ran konvensional.

\section{Catatan:}

Artikel ini ditulis dari tesis penulis di Pascasarjana Universitas Negeri Padang dengan tim pembimbing Dr. Irwan, M.Si dan Dr. Yerizon, M.Si.

\section{Daftar Rujukan}

Depdiknas. (2006). Sosialisasi Kuri-kulum Tingkat Satuan Pendi-dikan. Jakarta: Depdiknas

Fauzan, Ahmad. (2012). Modul1_peme-cahan_masalah. (Online),

(www.evaluasimatematika.net, diakses pada tanggal 12 April 2013)

- . (2012). Modul2_kemampuan_penalaran_dan_komunikasi. (Online),(www.evaluasimatematika.net, diakses pada tanggal 17 April 2013)

Hamruni. (2012). Strategi Pembelajaran. Yogyakarta: Insan Madani

NCTM. (2000). Principles and Standards for School Mathematics. Reston, VA: NCTM

PPPG. (2004). Pemecahan Masalah, Penalaran, dan Komunikasi. Yogyakarta: Depdiknas

Rusman. (2010). Model-model Pembelajaran "Mengembangkan Profesionalisme Guru” Edisi kedua. Jakarta: PT Raja Grafindo Persada

Uno, Hamzah B. dan Nurdin Mohamad. (2011). Belajar dengan pendekatan PAIL KEM. Jakarta: PT Bumi Aksara

Wena, Made. (2011). Strategi Pembelajaran Inovatif Kontemporer "Suatu Tinjauan Konseptual Operasional. Jakarta: PT Bumi Aksara 